\title{
Correction to: New Faces of Statelessness: The Rohingya Exodus and Remapping of Rights
}

\author{
Nergis Canefe
}

\section{Correction to:}

Chapter 11 in: N. Chowdhory and B. Mohanty (eds.),

Citizenship, Nationalism and Refugeehood

of Rohingyas in Southern Asia, https://doi.org/10.1007/978-981-15-2168-3_11

In the original version of the book, revised texts in many places are incorporated as post-publication corrections in the "Chapter 11". The chapter and the book now has been updated with changes. 